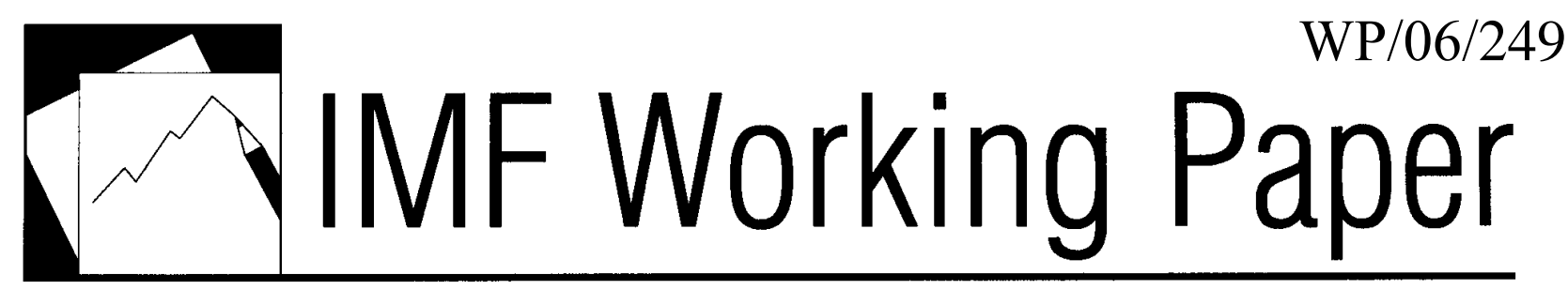

\title{
Testing Real Interest Parity in Emerging Markets
}

\author{
Manmohan Singh and Abhisek Banerjee
}





\title{
IMF Working Paper
}

\section{Middle East and Central Asia Department}

\section{Testing Real Interest Parity in Emerging Markets}

\author{
Prepared by Manmohan Singh and Abhisek Banerjee ${ }^{1}$ \\ Authorized for distribution by Ahsan Mansur
}

November 2006

\begin{abstract}
The views expressed in this Working Paper are those of the author(s) and do not necessarily represent those of the IMF or IMF policy. Working Papers describe research in progress by the author(s) and are published to elicit comments and to further debate.

The paper finds significant deviations between short-term emerging market real interest rates and world real interest rates primarily due to the inflationary expectations of the local investor base. We test for long-run real interest convergence in emerging markets using a time varying panel unit root test proposed by Pesaran to capture the improved macro-economic fundamentals since early 1990s. We also estimate the speed of convergence in the presence of a shock. The paper suggests that real interest rates in the emerging markets show some convergence in the long run but real interest parity does not hold. Our results also find that the speed of adjustment of real rates to a shock is estimated to differ significantly across the emerging markets. Measured by their half-life, some emerging markets in Asia, E.Europe and S.Africa, where real interest rates are generally low, take much longer to adjust than where real interest rates are generally high (Latin America, Turkey). From a policy perspective, encouraging foreign investors to take direct exposure at the short end of the local debt market could lower the real interest rates in some emerging markets.
\end{abstract}

JEL Classification Numbers: C23, F21, C22, F32

Keywords: real interest parity; short-term local emerging market debt; Pesaran's CADF test;

Author's E-Mail Address: msingh@imf.org

\footnotetext{
${ }^{1}$ We thank Lucio Sarno, Mahmood Pradhan, Miguel Savastano, Pradeep Kumar, Karen Parker, Francesc Balcells, Geoffrey Bannister, Marcelo Carvalho, and seminar participants within Middle East and Central Asia Department. We especially thank Kevin Lu Ji for valuable comments. Abhisek Banerjee is now a doctoral candidate with London School of Economics.
} 


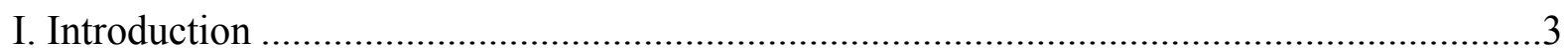

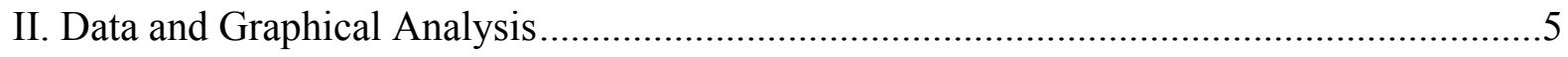

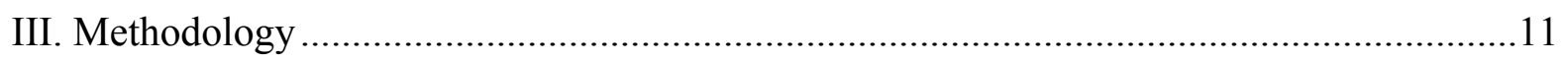

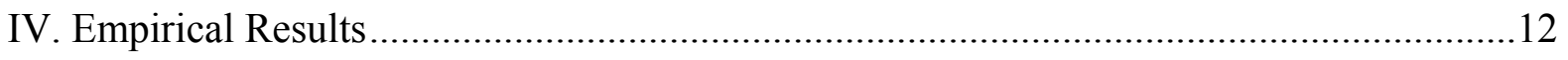

V. Conclusion and Policy Issues................................................................................. 13

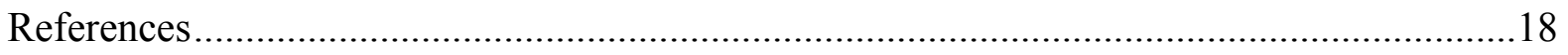

Boxes

1. Investor Base for Short-Term Emerging Market Debt .........................................6

Tables

1. Pesaran CADF Test for 3-Month Money Market Real Interest Rate Differentials of 14 EMs 1991:M1-2001M1.............................................................................. 14

2a. Mean and Convergence Speed of Real Interest Rates Using Actual Interest Rate Inflation................................................................................................ 15

2b. Mean and Convergence Speed of Real Interest Rates Using 6-month Moving-Average Inflation ............................................................................. 16

2c. Mean and Convergence Speed of Real Interest Rates Using Rational Expectation

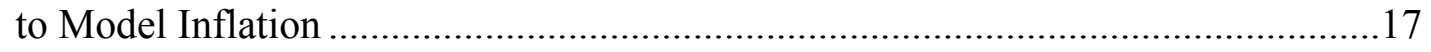

Figures

1. Selected Latin American Countries: Real Interest Rate Differentials .........................7

2. Selected EMEA Countries: Real Interest Rate Differentials .....................................8

3. Selected Countries in Crisis Asia: Real Interest Rate Differentials............................. 9

4. Other Selected Asian Countries: Real Interest Rate Differentials ............................10 


\section{INTRODUCTION}

Over the past 30 years, ever-increasing global integration in the financial and goods market has turned out to be one of the most significant and profound developments in the world economy. As a result, linkages among national financial markets have gradually strengthened, and an integrated international capital market has started to emerge. In theory, in a one-world market, investors should be able to allocate their capital freely, thereby reducing arbitrage opportunities across countries. In such an environment of growing interdependence among markets, country-specific interest rates should exhibit a long-run convergence trend. Such complete convergence is known as the real interest rate parity (RIP) hypothesis. Frankel (1979), for example, argues that long-run real interest rates should be equalized across countries and measures inflation differentials by long-term nominal interest differentials. Furthermore, the speed of convergence can be very fast, leaving monetary authorities with limited control over their real interest rate relative to other countries' real interest rates.

The long-run convergence of real rates for developed countries has attracted some attention, as in Tanner (1998); Obstfeld and Rogoff (2000); and Flood and Rose (2002). Tanner finds that in developing countries, high real interest rates stem from higher volatility in inflation and capital controls. Numerous studies on RIP have been done for developed countries: Cumby and Obstfeld (1984); Mishkin (1984); Cumby and Mishkin (1986); Blundell-Wignall and Browne(1991); Taylor (1991); and Fujii and Chinn (2000). ${ }^{2}$ These studies suggest that the evidence for RIP has been rather limited when short term data are used (i.e., with maturities of less than one year).

Most studies on this topic have used simple or panel regressions to address only the static behavior of short-term real rate differentials and have not adjusted for time-varying changes in the intercept. Taylor (2001) find that long-term real interest rate differentials are stationary and real interest rates in developed countries converge in the long run. Furthermore, there is little consensus regarding the rate of adjustment toward the world interest rate, which has important implications for monetary policy. ${ }^{3}$ In addition, it is not clear from the existing convergence studies whether capital movements are sufficient to equalize real rates across countries. Ferreira and Leon-Ledesma (2003) test for the real interest rate parity for both developed and emerging markets but do not adjust for a time-varying intercept to reflect the improved macro fundamentals (and hence lower real interest differentials over time) in emerging markets (EMs).

\footnotetext{
${ }^{2}$ See Fujii and Chinn (2000) for a brief survey.

${ }^{3}$ The emerging consensus in the literature seems to be that purchasing power parity (PPP) does hold in the long run for a large number of countries, with an adjustment speed in terms of half-life of approximately five to six years.
} 
The purpose of this paper is to examine whether real rates are converging in the long run across 14 EMs from 1991 to 2005. Since most EMs have improved fundamentals since 1991, the relatively lower inflationary environment results in lower real interest rate differentials. A simple panel data test would not capture this decline in real interest rate differentials. ${ }^{4}$ To capture this decline in interest rate differentials over time, we use Pesaran's (2003) cross-sectional augmented Dickey Fuller (CADF) test that uses a time varying intercept term, instead of a unit root test such as ADF (e.g., Ferreira and LeonLedesma). ${ }^{5}$ The usual critique of the ADF test is that it is associated with a low power that is biased in favor of accepting the null hypothesis. Furthermore, both the ADF and panel tests do not adjust for the

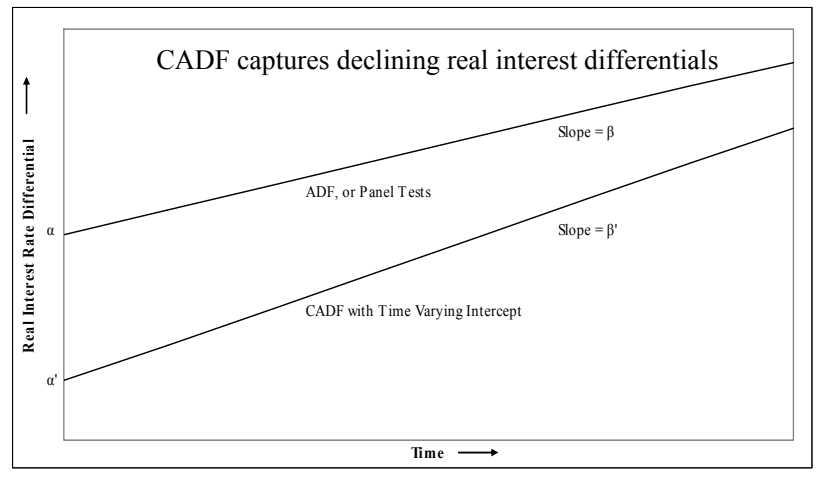
continuously time-varying intercept, as the CADF does. Thus the slope, $\beta$, of the crosssectional panel under CADF could be simple panel tests. To the best of our knowledge, this paper attempts CADF tests for the first time to test the real interest rate parity hypothesis. As explained later in the paper, the measure of the slope is crucial as it forms the null hypothesis of the CADF test. We also look at the half-life (in months) needed by the EMs to adjust toward their long-term real interest rate path, when faced with an exogenous shock.

If the real interest rate differential of a country is zero, there is complete convergence and RIP holds in the long run. Otherwise, there is incomplete convergence, which implies that there is no expectation that positive real interest differentials would disappear in the long run. RIP would not hold in the case of incomplete or partial convergence. Furthermore, the speed of adjustment to a shock can be obtained from this convergence framework.

Our main findings are as follows:

(1) Real interest parity does not hold in short-term EM debt from 1991 to 2005. We reject the hypothesis of zero mean rate differentials. This implies that in the long run, real interest rate differentials remain sizable in EMs and international capital mobility remains incomplete. We also provide some evidence that the investor base for short-term local emerging market debt is primarily domestic and continues to be averse to taking interest rate and credit risk given the history of inflation and devaluation in their countries.

(2) Given that there is evidence of incomplete convergence, the speed of adjustment of real rates to a shock (i.e., mean reversion) is higher on average than earlier studies and

\footnotetext{
4 Panel data with "fixed effects" requires dummy variables for structural breaks. More importantly, they do not adjust for the time-varying intercept that this paper tries to capture via the CADF. Panel data with "randomeffect" requires the assumption that individual country effects are not correlated with the error terms.

${ }^{5}$ Ferreira and Leon-Ledesma also use Perron's (1997) tests since most EM series contain structural changes. However, this test also does not adjust for the continuously time-varying intercept, as the CADF does.
} 
differs considerably across the 14 EMs. The average speed to adjust to the long-run real interest rate path as measured by the implied half-life is about 6 months - much higher than noted in earlier studies (Tanner, 1998; and Ferreira and Leon-Ledesma, 2003) - and is robust across three measures used to model inflation. We conclude that the results are primarily due to the inclusion of several EMs that were not included earlier studies (Asian and Eastern European countries) and the larger panel (our data span 15 years).

The remainder of the paper is organized as follows. Section II provides data and graphical analyses of real rate convergence. Section III reviews the existing literature on testing the short-run RIP and then introduces the panel data convergence approach. Section IV presents the empirical results. Some concluding remarks are provided in Section V.

\section{Data ANd Graphical Analysis}

The real interest rate is defined as the nominal interest rate less expected inflation. In order to construct the real interest rate, we need nominal interest rate data and inflation data. We use the monthly money market time series data from International Financial Statistics (IFS) of the International Monetary Fund (IMF), and cover the period from Q1 1991 through Q4 2005 for 14 EMs. The short-horizon real interest rates are obtained as the difference between the nominal interest rates of the money market and the expected inflation rate. ${ }^{6}$ The world real interest rate is a weighted average of the real interest rates of Japan, Germany, and the United States with the PPP share of world GDP as weights. The money market interest rates reflect market forces better than deposit rates. The consumer price index (CPI) is the price measure used to calculate inflation. Our sample includes Argentina, Brazil, Bulgaria, Indonesia, Korea, Malaysia, Mexico, Pakistan, Poland, Singapore, South Africa, Sri Lanka, Thailand, and Turkey. ${ }^{7}$

However, modeling inflation expectations is subject to measurement assumptions. Although one does not observe the expected inflation rate, it can be approximated by three general approaches. The first approach uses the unbiased hypothesis where we calculate ex post real interest differentials. The second approach assumes rational expectations. The third approach is to model inflationary expectations as a time series process. On the last approach, which proxies for inflationary expectations, the standard type time series models that are commonly used in the literature include the moving average models or use the Hodrick-Prescott (HP) filter.

In our study, we analyze the data using all three measure of inflation: that is, the unbiased hypothesis, the rational expectation measure, and the moving average method for proxying

\footnotetext{
${ }^{6}$ Long-term domestic rates are not available for most EMs since many have not (yet) developed their local bond markets and thus do not have yield curves with long maturities that can be compared — see Box 1 on investor base.

${ }^{7}$ Most transition countries in the CIS (including Russia) were not included due to incomplete data in the early to mid-1990s. Countries exhibiting administered or controlled rates like India and China were also excluded. Sub-Saharan francophone countries were excluded largely due to their peg with the French franc.
} 
inflationary expectations. On the latter, the expected inflation is calculated using a moving average (MA) filter consisting of six monthly lags of actual inflation. This moving average proxy of the expected inflation is widely adopted in the relevant literature. The empirical result stands robust to alternative ways of modeling expected inflation rates.

Graphical illustrations of real interest rate differentials (using actual ex post inflation) are summarized in Figures 1-4. Figure 1 summarizes the major Latin American countries (Argentina, Brazil, and Mexico) and suggests mostly positive real interest rate differentials. Figure 2 summarizes real interest rate differentials from selected countries in Eastern Europe, the Middle East, and Africa (Bulgaria, Poland, South Africa, and Turkey) where real interest rates appear mixed but have tended to be positive in recent years. Figures 3 and 4 highlight the primary countries that suffered in the Asian crisis (Indonesia, Korea, Malaysia, and Thailand) and also Pakistan, Singapore, and Sri Lanka.

\section{Box 1. Investor Base for Short-Term Emerging Market Debt}

Local investors remain the primary investors in money market and similar short-term instruments (such as CDs and T-bills) in emerging markets. The foreign investor base is keen on holding longer-term instruments, especially in recent years with the EMBI spread on dollar (and euro) denominated instruments offering below 200 basis points over comparable U.S. and Euro curves. The recent issue by Brazil of a 10-year bond denominated in reals to foreign investors highlights the risk averseness of local investors to longer-dated instruments. Thus despite the severe maturity mismatch by Brazilian pension funds, they prefer short-dated papers (in a relatively flat yield curve environment). Foreigners may not be active at the short end of the curve directly as they prefer to mimic such exposure offshore via credit-linked notes, non-deliverable forwards (NDF), or total return swaps written on T-bills and CDs. Mexico is a good example, where foreigners are active throughout the yield curve but only real money investors take direct exposure on longer-duration assets while the short end of the curve is played via swaps and other derivative instruments.

Local regulations may also create a bias in favor of local investors (e.g., until recently, foreigners were taxed on short-term Brazilian debt and received similar treatment in Thailand). Other countries, such as India, have a cap on foreign investors in the local bond market (only 1 percent of the Indian government bond market is open to foreign investors). Similarly, most of the recent debt exchanges by Mexico in favor of peso instruments at the long end of the curve were targeted to the foreign investor base. Market sources indicate that a lack of standardized securities clearance and settlement mechanisms keeps foreign investors away from participating directly in short-term local debt. Furthermore, real money investors are not interested at the short end. Although ELMI (a local index) tracks local money market instruments, there no broad-based comparable indices like the EMBI for short-term rates in local markets. Furthermore, the lack of a repo market at the shortend of the curve keeps foreign investors away.

There has been sizable volatility in some of the EM, currencies since the Asian crisis. Local investors who are circumspect of past (and expectations of future) inflationary episodes and ensuing devaluation thus continue to bid successfully for higher interest rates at the short end of local EM debt. 
Figure 1. Selected Latin American Countries: Real Interest Rate Differentials

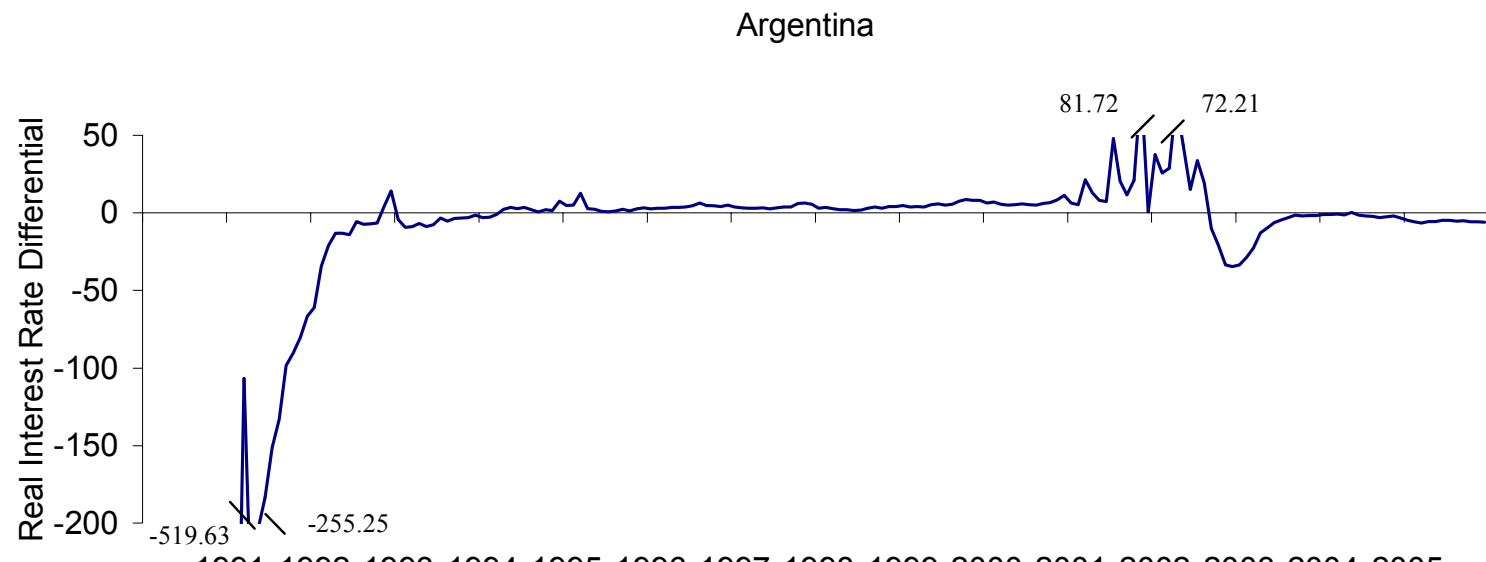

199119921993199419951996199719981999200020012002200320042005

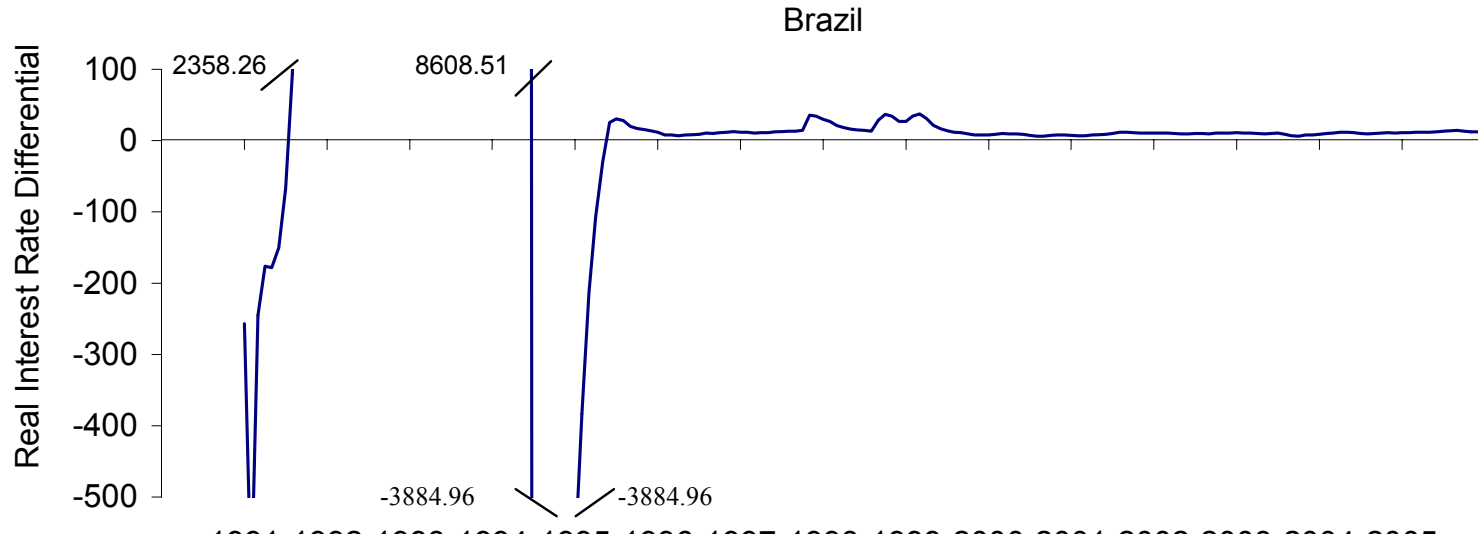

199119921993199419951996199719981999200020012002200320042005

Mexico

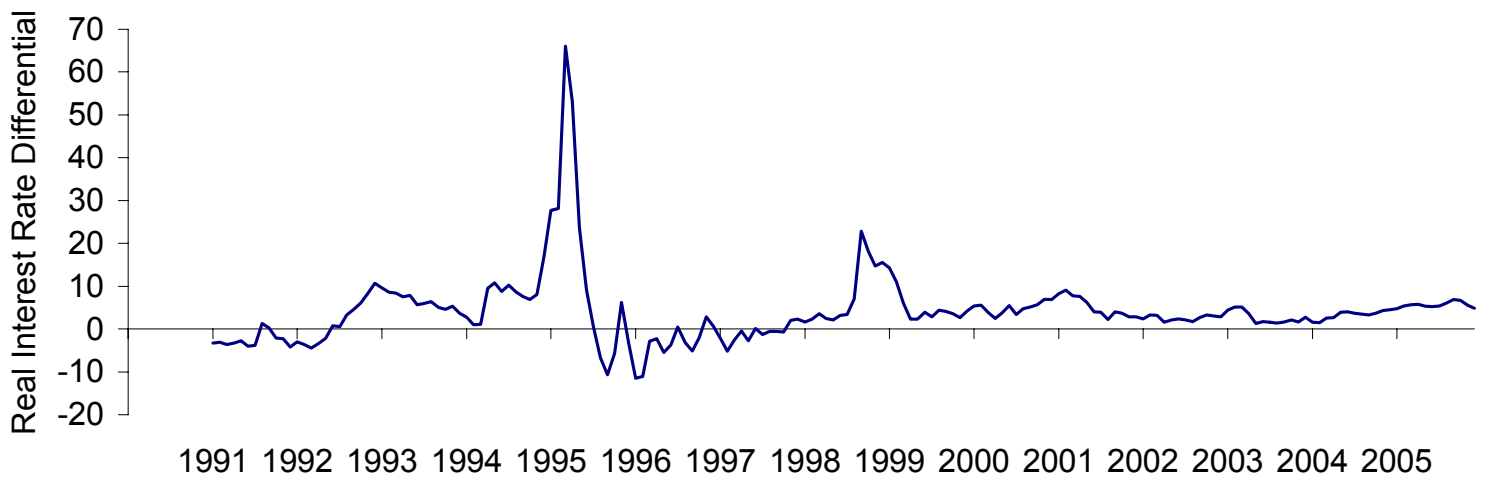

Source: International Financial Statistics. 
Figure 2. Selected EMEA Countries: Real Interest Rate Differentials
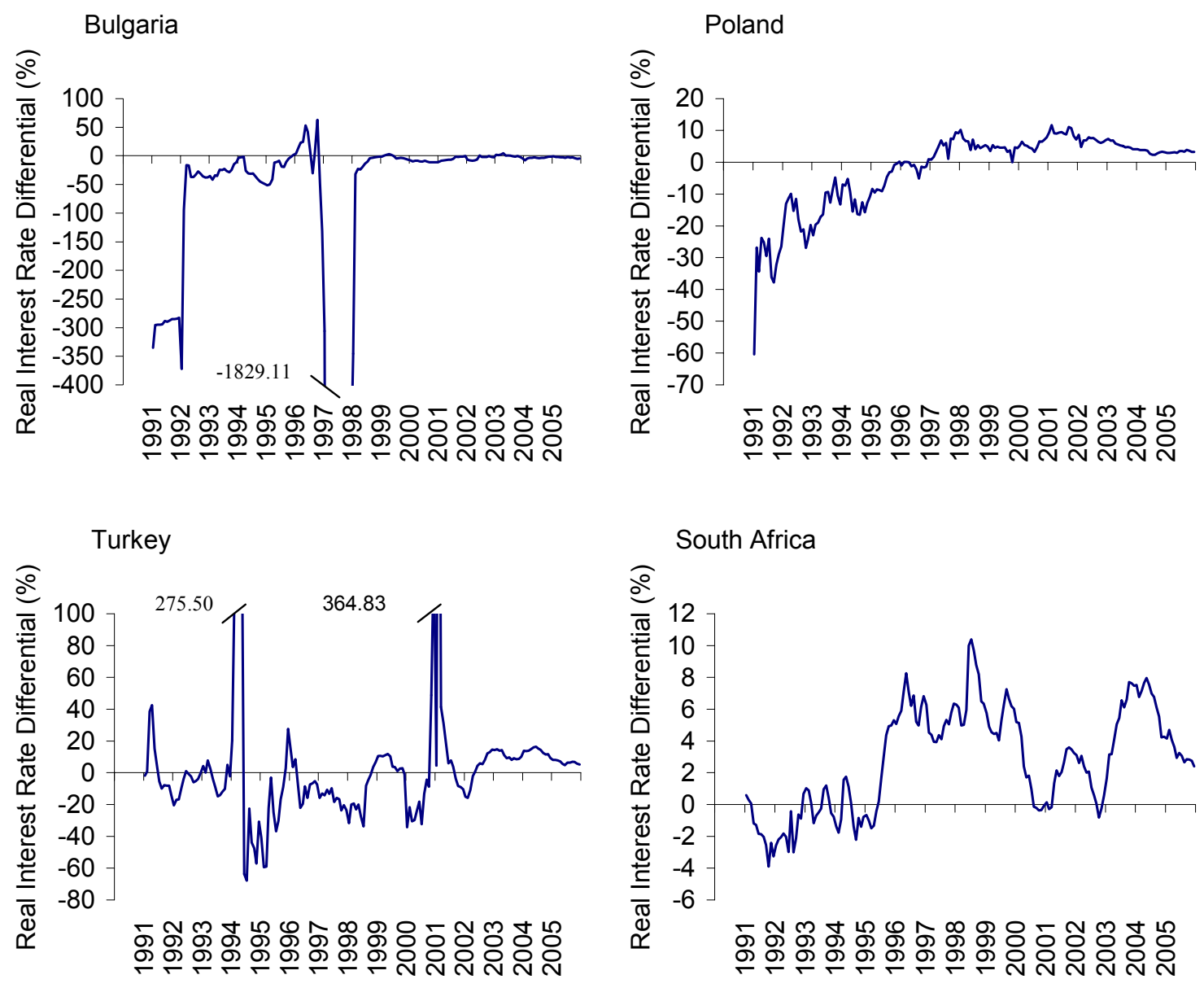

Source: International Financial Statistics. 


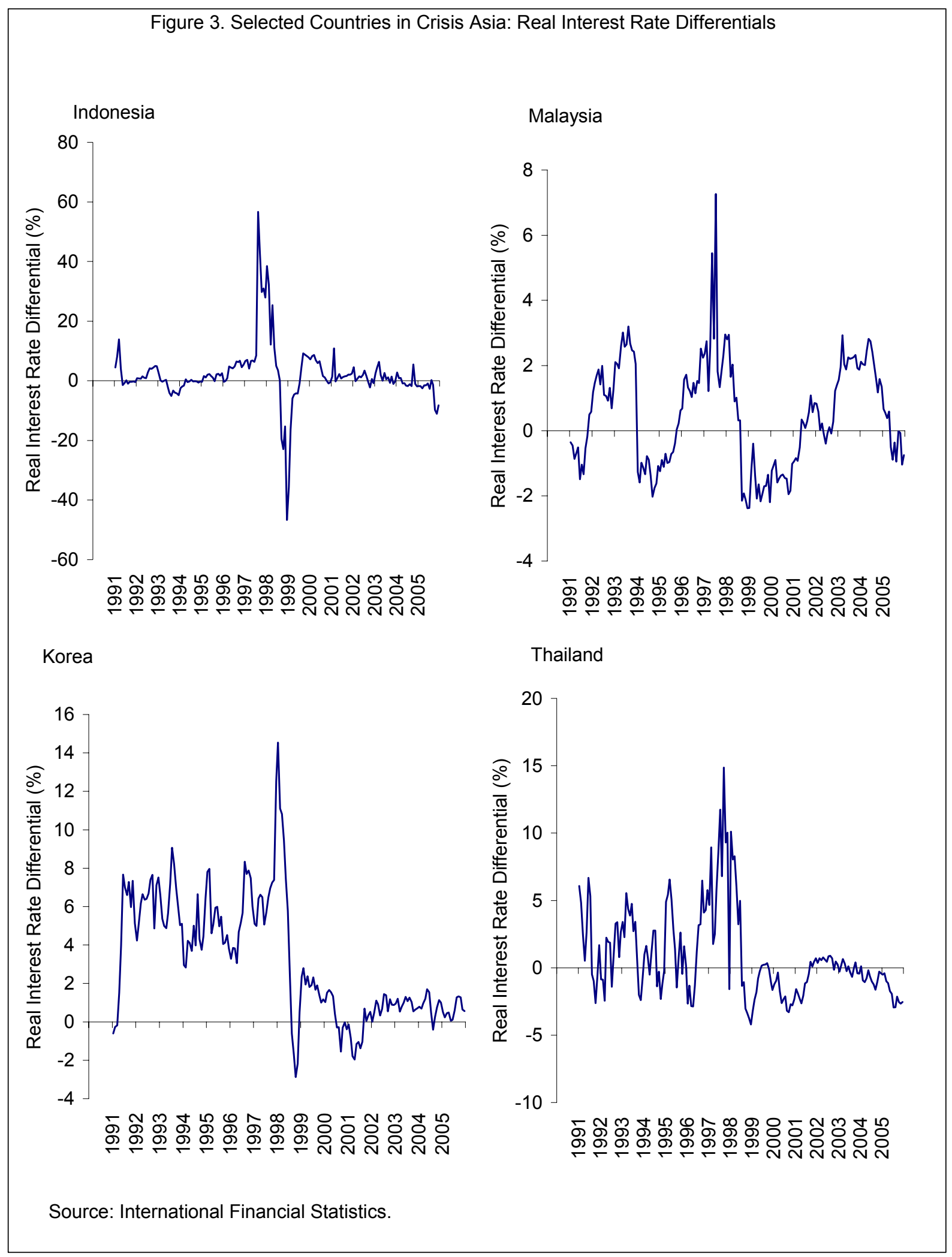




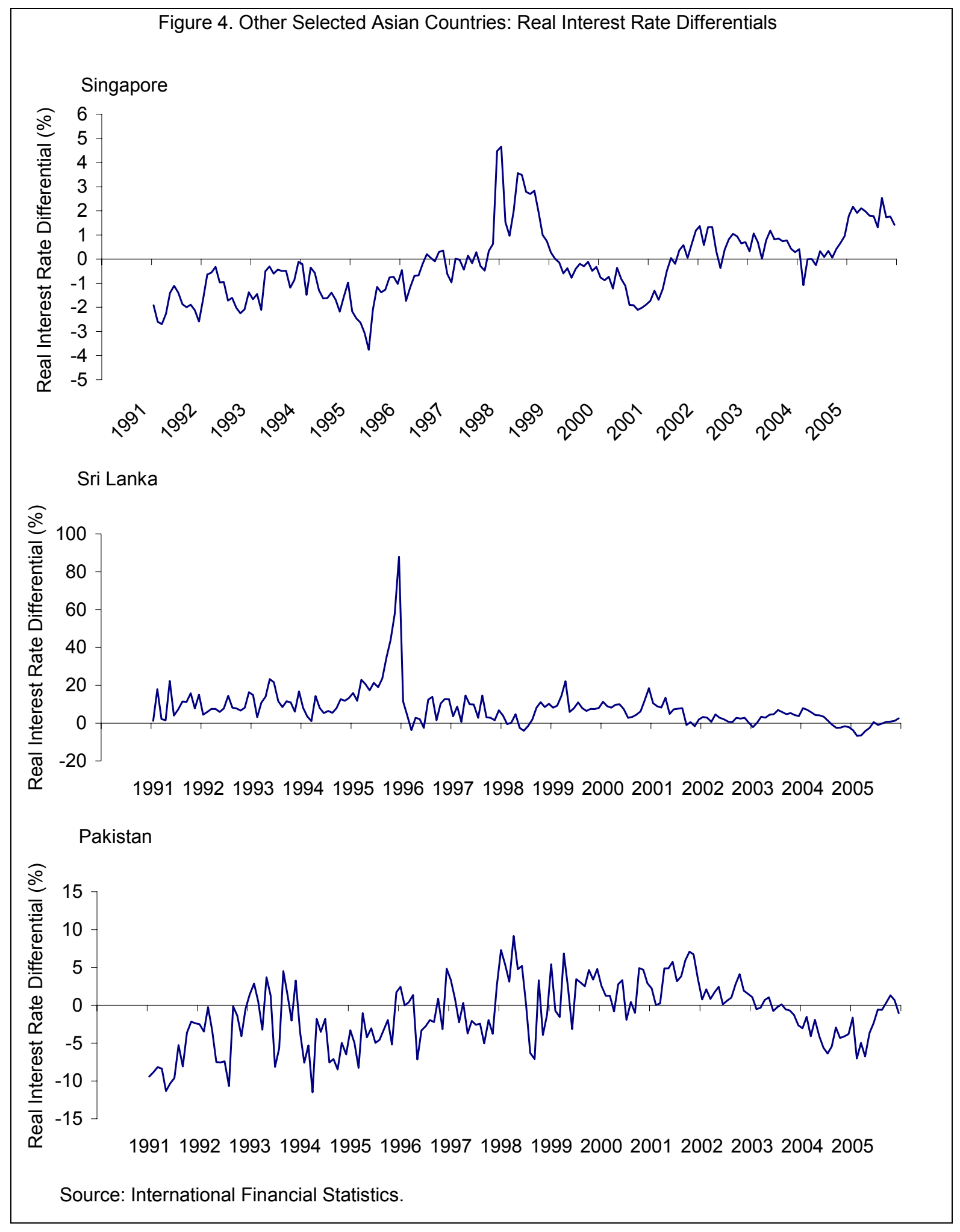


The graphs do not exhibit any clear-cut conclusions to our question of whether real rates are converging and/or equalizing across the countries in the long run. We thus use a systematic econometric methodology to analyze this further.

\section{Methodology}

The view that countries' real interest rates should converge to a world real rate level can be derived using two conditions. We assume that Uncovered Interest Parity (UIP) and Purchasing Power Parity (PPP) hold.

The UIP means that the real interest rate differential equals the expected change in the nominal exchange rate as follows

$$
E(\Delta e)=i_{k}-i * f
$$

where $i_{k}$ and $i^{*}$ are the nominal interest rates of country $\mathrm{k}$ and the world, respectively. $\mathrm{E}(\Delta \mathrm{e})$ is the expected change in the real exchange rates and $f$ is the currency risk premium. In addition, assume relative PPP holds, so that the expected exchange rate change equals the expected inflation differential

$$
\mathrm{E}(\Delta \mathrm{e})=\mathrm{E}\left(\pi_{\mathrm{k}}-\pi^{*}\right)
$$

where $\pi_{\mathrm{k}}$ and $\pi^{*}$ are the inflation rates of country $\mathrm{k}$ and the world, respectively. Combining equation (1) and (2), and rearranging terms:

$$
\left[\mathrm{i}_{\mathrm{k}}-\mathrm{E}\left(\pi_{\mathrm{k}}\right)\right]-\left[\mathrm{i}^{*}-\mathrm{E}\left(\pi^{*}\right)\right]=\mathrm{f}
$$

where $\mathrm{i}_{\mathrm{k}}-\mathrm{E}\left(\pi_{\mathrm{k}}\right)$ and $\mathrm{i}^{*}-\mathrm{E}\left(\pi^{*}\right)$ are real rates $r_{k}$ and $\mathrm{r}^{*}$ for country $\mathrm{k}$ and the world, respectively.

This is to say that in Equation (3) if $f$ is stationary, it implies long-run convergence; also it has a better chance to hold in the long run rather than in the short run. Furthermore, if $f$ is not only stationary but also equal to zero, it implies complete convergence, that is, RIP holds. If $f$ is stationary but not equal to zero, it implies incomplete convergence. If $f$ is nonstationary, however, Equation (3) implies divergence of real interest rates.

The hypothesis that RIP holds is given by $\mathrm{H}_{0}: \beta_{k}=0$ and $\mathrm{H}_{1}: \beta_{k} \neq 0$. This can be framed into a panel unit root test and thus overcomes the low power problem of a univariate unit root test. If the real interest differential has a unit root, this implies that real interest rates, $r$, are not converging.

We have:

$$
\Delta\left(r_{k t}-r_{t}^{*}\right)=\mu_{k}+\beta_{k}\left(r_{k, t-1}-r_{t-1}^{*}\right)+c_{i}\left(\overline{r_{k, t-1}-r_{t-1}^{*}}\right)+\sum_{m=0}^{p_{k}} d_{k, m} \Delta\left(\overline{r_{k, t-m}-r_{t-m}^{*}}\right)+\sum_{m=1}^{p_{k}} \phi_{k, m} \Delta\left(r_{k, t-m}-r_{t-m}^{*}\right)+\eta_{k t}
$$


where $k=1,2, \ldots \ldots, \mathrm{N} ; \mathrm{t}=1,2, \ldots \ldots, \mathrm{T}$;

$\mu_{k}$ together with the two average interest rate differential terms (with coefficients $c_{i}$ and $d_{k, m}$ ) is a time-varying constant term that captures the reduction in real interest rate differentials in the EMs in the past 15 years,

$\beta_{k}$ is the coefficient of the first lag real interest rate differential and,

$\varphi_{\mathrm{k}, \mathrm{m}}$ is the coefficient of all other lag real interest rate differentials.

The approximate half-life of a shock to $r_{k}$ is computed as $-\ln (2) / \ln \left(1+\beta_{k}\right)$. The half-life gives us important information about how quickly real rates would converge to their equilibrium long-run path after a shock (or, the time needed for deviations from UIP to die out).

\section{EMPIRICAL RESULTS}

In this section we present and discuss the results of the convergence test described in the previous section. The CADF t-bar test is applied to Equation (4) to test if the real interest rate differentials have a unit root. $^{8}$ The results are presented in Table 1 . The t-bar test statistics are generally robust to the choice of the order of augmentation of the underlying CADF regressions. ${ }^{9}$ In order to make the speed of convergence much more readily interpretable, we compute the half-life of the convergence process, which is the number of time periods (months) it takes for a shock to the real interest rate differential to disappear.

Overall, the results imply that the real interest rates across the EMs are converging, and table 1 shows that for the short-horizon real interest rates, the CADF t-bar test statistic strongly rejects the null hypothesis of a unit root at the 5 percent (and even 1 percent) confidence level. We find that the results are robust across all three measures of inflation expectation. We reject the null hypothesis that the means of the real interest rate differentials are zero; therefore RIP does not hold. ${ }^{10}$ Furthermore, the aggregate " $t$ " test suggests that the real interest rates are significantly different from zero, implying that there is partial convergence.

\footnotetext{
Although our study finds partial convergence, it also suggests a higher premium to shocks after the Asian crisis. The outer column of Tables $2 \mathrm{a}, 2 \mathrm{~b}$, and $2 \mathrm{c}$ measures half-lives

${ }^{8}$ The appropriate choice of $\mathrm{p}_{\mathrm{k}}$ (or, the lag order) is important for the validity of the ADF (augmented Dickey Fuller) test. The Akaike Information Criteria (AIC) is used to choose the lag order of each individual country.

${ }^{9}$ In the interest of space, we report only the table with results for the case with maximum truncations of 8 for the short-horizon real interest rates.

${ }^{10}$ The six-month moving average method was not used as this statistic smooths the average by construction and thus incorrectly reduces the standard errors.
} 
on the average of 5.5 to 7 months across all three measures of inflation. Although half-lives vary significantly across country, this study finds that it takes more than twice the time, on average, than that calculated in Tanner (1998) and Ferreira and Leon-Ledesma (2003) for countries that deviate from UIP. This is largely due to the inclusion of Asian countries and Eastern European countries where half-lives are sizably larger than in Latin American countries or in Turkey. This may be because countries such as Korea, Singapore, Bulgaria, Poland, Malaysia, Thailand, and South Africa are associated with lower real interest rates than Latin countries (Argentina, Brazil or Mexico) and Turkey. Deviations from a lower real interest rate environment (closer to world rates) comes more as a surprise, and thus slower mean reversion. However, deviations in countries that have on average large real interest rates revert faster to their mean. Although counter intuitive, market sources indicate that high-yield investors that prefer the Latin countries or Turkey's relative high interest rate environment do not stay on the sidelines too long especially if nominal interest rates stay well above double digits.

\section{Conclusion ANd Policy ISSUes}

Over the past decade and a half, improved macroeconomic fundamentals in EMs have resulted in their short-term real interest rates converging (partially) with world real interest rates. Convergence and its extreme case of real interest rate parity (RIP), present national monetary authorities with the question of how to use monetary policy effectively. In an open economy, a necessary pre condition for the monetary policy transmission mechanism to function successfully is to allow real rates to differ across countries by controlling nominal rates. Our study suggests little empirical evidence for the long-run convergence of short-term real interest rates in the EMs. Furthermore, shocks to some EMs result in a longer time interval for real interest rate differentials to converge to their ex ante levels.

From a policy perspective, there are some interesting issues for further research. Foreign investors usually prefer to take indirect exposure at the short end of the local debt market. Bringing them onshore may lower the real interest rates in some EMs. To this end, the local authorities could facilitate a repo market, standardize securities clearance and settlement mechanisms, and provide for a broad based local index that tracks local money market instruments to entice real money accounts that usually benchmark their investments to indices.

Also in presence of a shock, we find that countries that are usually associated with a lower real interest rate environment may find mean reversion to their trend rates slower relative to those that generally exhibit higher real interest rates. As an extension of this topic, it would be interesting to better understand why mean reversion is faster in the Latin region than ion Asia. Also, another extension would be to apply CADF to developed countries, especially in light of the events faced by Iceland and New Zealand this year. ${ }^{11}$

\footnotetext{
${ }^{11}$ This year, the nominal 3 month interest rates reached 14 percent in Iceland (and adjusting for actual inflation), real interest rates were around 6 percent—high for a developed market. Similarly, New Zealand nominal rates reached 7.25 percent (and real interest rates at around 3.5\%) with higher real returns possible due to the volatility in the Kiwi dollar.
} 
Table 1. Pesaran CADF Test for 3-Month Money Market Real Interest Rate Differentials of 14 EMs 1991:M1-2001M1

\begin{tabular}{|l|c|c|c|}
\hline $\begin{array}{l}\text { Regression with inflation } \\
\text { measured as: }\end{array}$ & t-bar test & $\begin{array}{c}5 \% \\
\text { significance } \\
\text { (cut-off } \\
\text { value from } \\
\text { Pesaran's } \\
\text { table) }\end{array}$ & $\begin{array}{c}1 \% \text { significance } \\
\text { (cut-off values } \\
\text { from Pesaran's } \\
\text { table) }\end{array}$ \\
\hline Ex post (unbiased hypothesis) & -3.918 & -2.25 & -2.42 \\
\hline Rational expectation & -3.969 & -2.25 & -2.42 \\
\hline Moving average (6 months) & -3.721 & -2.25 & -2.42 \\
\hline $\begin{array}{l}\text { Note: The order of lags for each individual differential series is selected by Akaike } \\
\text { information criteria. The critical values for the t-bar test are obtained from Pesaran } \\
\text { (2003) CADF tables. The appropriate choice of p p }\end{array}$ \\
for the validity of the ADF (augmented Dickey Fuller) test. \\
\hline
\end{tabular}


Table 2a. Mean and Convergence Speed of Real Interest Rate Using Actual Interest Rate Inflation

\begin{tabular}{|l|r|r|r|r|r|}
\hline Country & $\begin{array}{c}\text { Intercept } \\
\text { (mean) }\end{array}$ & $\begin{array}{c}\mathrm{t} \text {-value } \\
\text { of } \\
\text { Intercept }\end{array}$ & \multicolumn{1}{c|}{$\mathrm{b}_{\mathrm{k}}$} & \multicolumn{1}{c|}{$\begin{array}{c}\text { t-value } \\
\text { of } b_{\mathrm{k}}\end{array}$} & \multicolumn{1}{|c|}{$\begin{array}{c}\text { Half-life } \\
\text { (month) }\end{array}$} \\
\hline Argentina & 0.54308 & 0.69722 & -0.2044 & -5.3148 & 3.0 \\
\hline Brazil & 106.414 & 1.42966 & -0.423 & -1.9851 & 1.3 \\
\hline Bulgaria & -11.07 & -1.198 & -0.1033 & -3.6554 & 6.4 \\
\hline Indonesia & 0.69315 & 1.44043 & -0.2666 & -4.5106 & 2.2 \\
\hline Korea & 0.11693 & 0.95761 & -0.045 & -1.582 & 15.1 \\
\hline Malaysia & 0.05125 & 0.82777 & -0.09 & -2.4597 & 7.3 \\
\hline Mexico & 1.05082 & 4.60649 & -0.2946 & -9.1437 & 2.0 \\
\hline Pakistan & -0.0619 & -0.2561 & -0.2405 & -3.1705 & 2.5 \\
\hline Poland & 0.44497 & 2.67504 & -0.0949 & -5.5155 & 6.9 \\
\hline South Africa & 0.14207 & 1.65382 & -0.0444 & -2.2495 & 15.3 \\
\hline Sri Lanka & 2.74442 & 3.75386 & -0.3462 & -6.0712 & 1.6 \\
\hline Singapore & 0.01621 & 0.32938 & -0.0948 & -2.6417 & 7.0 \\
\hline Thailand & 0.06357 & 0.39348 & -0.1601 & -2.7409 & 4.0 \\
\hline Turkey & 0.30679 & 0.10724 & -0.6245 & -5.9996 & 0.7 \\
\hline Average & & & & & 5.4 \\
\hline
\end{tabular}


Table 2b. Mean and Convergence Speed of Real Interest Rate Using 6-Month MovingAverage Inflation

\begin{tabular}{|l|r|r|c|r|r|}
\hline Country & $\begin{array}{c}\text { Intercept } \\
\text { (mean) }\end{array}$ & $\begin{array}{c}\mathrm{t} \text {-value of } \\
\text { Intercept }\end{array}$ & \multicolumn{1}{c|}{$\mathrm{b}_{\mathrm{k}}$} & \multicolumn{1}{c|}{-value of $\mathrm{b}_{\mathrm{k}}$} & \multicolumn{1}{|c|}{$\begin{array}{c}\text { Half-life } \\
\text { (months) }\end{array}$} \\
\hline & & & & & 1.7 \\
\hline Argentina & 0.68641 & 0.73322 & -0.3398 & -13.867 & 1.7 \\
\hline Brazil & 87.6413 & 1.03978 & -0.3367 & -1.6017 & 22.1 \\
\hline Bulgaria & -3.2806 & -1.2722 & -0.0308 & -3.0374 & 2.9 \\
\hline Indonesia & 0.55876 & 1.18479 & -0.2096 & -4.9425 & 12.6 \\
\hline Korea & 0.14368 & 1.238 & -0.0536 & -1.9985 & 3.8 \\
\hline Malaysia & 0.04364 & 0.79106 & -0.0853 & -2.776 & 2.5 \\
\hline Mexico & 0.799 & 3.78442 & -0.2006 & -8.4568 & 15.2 \\
\hline Pakistan & -0.1152 & -0.4889 & -0.2437 & -3.2309 & 13.7 \\
\hline Poland & 0.07686 & 0.39629 & -0.0444 & -2.544 & 2.0 \\
\hline South Africa & 0.14574 & 2.11079 & -0.0494 & -2.9543 & 11.0 \\
\hline Sri Lanka & 2.32435 & 3.31615 & -0.2951 & -5.5098 & 3.8 \\
\hline Singapore & 0.01035 & 0.25367 & -0.0611 & -1.9104 & 0.7 \\
\hline Thailand & 0.1131 & 0.68877 & -0.1673 & -3.6017 & 7.2 \\
\hline Turkey & -0.0414 & -0.0149 & -0.6264 & -6.2628 & \\
\hline Average & & & & & \\
\hline
\end{tabular}


Table 2c. Mean and Convergence Speed of Real Interest Rate Using Rational Expectation to Model Inflation

\begin{tabular}{|l|r|r|r|r|r|}
\hline Country & \multicolumn{1}{|l|}{$\begin{array}{l}\text { Intercept } \\
\text { (mean) }\end{array}$} & $\begin{array}{l}\text { t-value of } \\
\text { Intercept }\end{array}$ & \multicolumn{1}{l|}{$b_{k}$} & \multicolumn{1}{l|}{ t-value of $b_{k}$} & $\begin{array}{l}\text { Half-life } \\
\text { (months) }\end{array}$ \\
\hline & & & & & 5.0 \\
\hline Argentina & 0.48842 & 0.50438 & -0.1294 & -4.3205 & 1.5 \\
\hline Brazil & 97.7124 & 1.30159 & -0.3623 & -1.5976 & 6.2 \\
\hline Bulgaria & -11.198 & -1.1906 & -0.1062 & -3.6359 & 3.2 \\
\hline Indonesia & 0.3879 & 0.88923 & -0.1973 & -3.8674 & 15.9 \\
\hline Korea & 0.10864 & 0.86424 & -0.0427 & -1.4697 & -2.611 \\
\hline Malaysia & 0.06653 & 1.04934 & -0.0997 & -8.5539 & 1.7 \\
\hline Mexico & 1.19965 & 4.84178 & -0.3281 & -3.485 & 2.5 \\
\hline Pakistan & -0.0969 & -0.4129 & -0.2431 & -3.5409 & 9.3 \\
\hline Poland & 0.39219 & 2.04005 & -0.0715 & -2.2975 & 14.9 \\
\hline South Africa & 0.15446 & 1.76024 & -0.0455 & -6.0477 & 1.6 \\
\hline Sri Lanka & 2.74726 & 3.75879 & -0.3447 & -2.7977 & 6.3 \\
\hline Singapore & 0.01834 & 0.35112 & -0.1047 & -2.6875 & 3.8 \\
\hline Thailand & 0.0688 & 0.41269 & -0.1669 & -5.943 & 0.7 \\
\hline Turkey & 0.59516 & 0.21586 & -0.6048 & & 5.7 \\
\hline Average & & & & &
\end{tabular}




\section{References}

Blundell-Wignall, Adrian and Frank Browne, 1991, "Increasing Financial Market Integration: Real Exchange Rates and Macroeconomic Adjustment," OECD Working Paper.

Breedon Francis, Henry Brian and Williams Geoffrey. 1999, "Long-term Real Interest Rates: Evidence on the Global Capital Market," Oxford Review of Economic Policy, Vol. 15. No. 2, pp.128-42.

Breitung, J. and W. Mayer, 1994, "Testing for Unit Roots in Panel Data: Are Wages on Different Bargaining Levels Cointegrated?” Applied Economics, Vol. 26, pp. 353-61.

Chortareas, G.E. and R.L. Driver, 2001, "PPP and the Real Exchange Rate-Real Interest Rate Differential Puzzle Revisited: Evidence from Non-Stationary Panel Data,” Bank of England, working paper.

Cumby, R.E. and M. Obstfeld, 1984, "International Interest Rate and Price Level Linkages under Flexible Exchange Rates: A Review of Recent Evidence," in Exchange Rate Theory and Practice, ed. by J.F.O. Bilson and R.C. Marston (Chicago: University of Chicago Press).

Edison, H.J. and B.D. Pauls, 1993, "A Re-Assessment of the Relationship Between Real Exchange Rates and Real Interest Rates: 1974-90," Journal of Monetary Economics, Vol. 31, pp. 165-87.

Evans, Paul and Georgios Karras, 1996, "Convergence Revisited," Journal of Monetary Economics, Vol 37(2), pp. 249-65.

Ferreira, Alex Luiz and Miguel Leon-Ledesma, 2003, "Does the Real Interest Parity Hypothesis Hold? Evidence for Developed and Emerging Markets," Working paper, University of Kent.

Flood, Robert, and Andrew Rose, 2002, "Uncovered Interest Parity in Crisis," Staff Papers, International Monetary Fund, Vol. 49, No 2.

Frankel, J. 1979, “A Monetary Approach to the Exchange Rate: Doctrinal Aspects and Emprical Evidence,” Scandinavian Journal of Economics., May, 78, 200-24

Frankel, Jeffrey, Sergio Schmukler and Luis Serven, 2002, "Global Transmission of Interest Rates: Monetary Independence and Currency Regime," NBER, Working paper number 8828.

Fujii, Eiji and David Menzie Chinn, 2000, “Fin de Siecle Real Interest Parity,” NBER Working Paper, No W7880

Jorion, P. 1996, “Does real interest parity hold at longer maturities?” Journal of International Economics, Vol. 40, pp. 105-26. 
Levin, Andrew and Lin Chien-fu, 1992, "Unit Root Tests in Panel Data: Asymptotic and Finite-Sample Properties,” Working Paper, Economics Department, UCSD, San Diego.

Levin, Andrew and Lin Chien-fu, 1993, "Unit Root Test in Panel Data: New Results," Working Paper, Economics Department, UCSD, San Diego.

MacDonald, R. and J. Nagayasu, 2000, “The Long-Run Relationship Between Real Exchange Rates and Real Interest Rate Differentials: A Panel Study," Staff Papers, International Monetary Fund Vol. 47.

Mandela G. S. and S. Wu, 1996, "A Comparative Study of Unit Root Tests with Panel Data and a New Simple Test," paper presented at the Econometric Society Meetings, New Orleans.

Mark, N, 1985, "Some Evidence on the International Inequality of Real Interest Rates," Journal of International Money and Finance, Vol. 4, pp. 189-208.

Meuse, R. and K. Roof, 1988, "Was it real? The exchange rate interest rate differential relation over the modern floating-rate period," Journal of Finance, Vol. XLIII, pp. 933-48.

Meredith, G. and M.D. Chinn, 1998, “Long-Horizon Uncovered Interest Parity,” NBER Working Paper 6797.

Mish kin, F.S., 1984, “Are Real Interest Rates Equal Across Countries? An Empirical Investigation of International Parity Conditions," Journal of Finance, Vol. 39, pp.1345-57.

Modjtahedi, B., 1988, "Dynamics of real interest differentials: An empirical investigation," European Economic Review, Vol. 32, pp.1191-211.

Obstfeld, Maurice, and Kenneth Rogoff, (1995a), "Exchange Rate Dynamics Redux", Journal of Political Economy, pp. 624-660.

Obstfeld, Maurice \& Rogoff, Kenneth, 2000," The Six Major Puzzles in International Economics: Is there a Common Cause? In NBER Working Paper 7777.

Perron, P.1997, "Further Evidence on Breaking Trend Functions in Macroeconomic Variables," Journal of Econometrics, 80,2,355-385

Pesaran, Hashem M., 2003, “A Simple Panel Root Test in the Presence of Cross Section Dependence," CWPE, working paper, Vol. 0346.

Rose, A. K., 1989, “Is the real interest rate stable?” Journal of Finance, Vol. 48, pp. 1095112. 
Tanner, E., 1998, "Deviations from Uncovered Interest Parity: A Global Guide to Where the Action Is” IMF Working Paper, 98/117 (Washington: International Monetary Fund).

Taylor, M.P., 1991, “Testing Real Interest Parity in the European Monetary System,” Bank of England, Working Paper.

Taylor, John, (2001), “The Role of Exchange Rate in Monetary-Policy Rules”, American Economic Review, Papers and Proceedings, pp. 263-267. 